\title{
SEROEPIDEMIOLOGY OF INFECTION WITH NEOSPORA CANINUM, LEPTOSPIRA, AND BOVINE HERPESVIRUS TYPE 1 IN WATER BUFFALOES (BUBALUS BUBALIS) IN VERACRUZ, MEXICO
}

\author{
Dora Romero-Salas $^{1}$, Cosme Alvarado-Esquivel ${ }^{2, *}$, Gladys Domínguez-Aguilar ${ }^{1}$, Anabel Cruz-Romero ${ }^{1}$, \\ Nelly Ibarra-Priego ${ }^{1}$, Carolina Barrientos-Salcedo ${ }^{3}$, Mariel Aguilar-Domínguez ${ }^{1}$, Rodolfo Canseco-Sedano ${ }^{1}$, \\ Luz Teresa Espín-Iturbe ${ }^{1}$, Luis Francisco Sánchez-Anguiano ${ }^{4}$, Jesús Hernández-Tinoco ${ }^{4}$, \\ Adalberto A. Pérez de León 5 \\ ${ }^{1}$ Laboratorio de Parasitología, Facultad de Medicina Veterinaria y Zootecnia, Universidad Veracruzana, Circunvalación y Yáñez \\ S/N, C.P. 91710, Veracruz, México \\ ${ }^{2}$ Laboratorio de Investigación Biomédica, Facultad de Medicina y Nutrición, Universidad Juárez del Estado de Durango, Avenida \\ Universidad S/N, 34000 Durango, México \\ ${ }^{3}$ Laboratorio de Química Médica y Quimiogenómica, Facultad de Bioanálisis Región Veracruz, Agustín de Iturbide Esq. Carmen \\ Serdán S/N, Col. Centro, C.P. 91700 México \\ ${ }^{4}$ Instituto de Investigación Científica "Dr. Roberto Rivera Damm”, Universidad Juárez del Estado de Durango, \\ Avenida Universidad S/N, 34000 Durango, México \\ ${ }^{5}$ US Department of Agriculture - Agricultural Research Service, Knipling-Bushland U.S. Livestock Insects Research Laboratory, \\ and Veterinary Pest Genomics Center, Kerrville, Texas, 78028, USA
}

Received: August 31, 2017; Accepted: September 7, 2017

We aimed to determine the seroprevalence of infection with Neospora caninum, Leptospira, and bovine herpesvirus type 1 and risk factors associated with these infections in water buffaloes in Veracruz State, Mexico. Through a cross-sectional study, 144 water buffaloes (Bubalus bubalis) raised in 5 ranches of Veracruz were examined for anti- $N$. caninum and anti-bovine herpesvirus type 1 antibodies by enzyme immunoassays, and anti-Leptospira interrogans antibodies by microscopic agglutination test.

Of the 144 buffaloes studied, 35 (24.3\%) were positive for $N$. caninum, 50 (34.7\%) for Leptospira, and 83 (57.6\%) for bovine herpes virus. The frequencies of leptospiral serovars in buffaloes were as follows: $18.7 \%$ for Muenchen $(n=27), 10.4 \%$ for Hardjo LT $(n=15), 9.0 \%$ for Pyrogenes $(n=13)$, and $4.8 \%$ for Icterohaemorrhagiae $(n=7)$. Seropositive buffaloes were found in all 5 ranches studied. Logistic regression showed that cohabitation of buffaloes with cows was associated with infection with Leptospira (odds ratio [OR], 2.2; 95\% confidence interval $[\mathrm{CI}], 1.04-4.5 ; P=0.03)$ and bovine herpesvirus $(\mathrm{OR}, 12.0 ; 95 \% \mathrm{CI}, 4.0-36.2 ; P<0.01)$.

This is the first study that provides serological evidence of $N$. caninum, Leptospira, and bovine herpesvirus type 1 infections in water buffaloes in Mexico. Our findings could be used to enhance preventive measures against these infections.

Keywords: Neospora, Leptospira, bovine herpesvirus, water buffaloes, seroprevalence, Mexico

\section{Introduction}

Neospora caninum (N. caninum), Leptospira, and bovine herpesvirus type 1 are important infectious pathogens that lead to bovine abortion, neonatal mortality, and birth of weak calves [1]. The protozoan $N$. caninum is an obli- gate intracellular parasite in the Apicomplexa phylum that causes Neosporosis [2, 3]. Neosporosis affects domestic and wild animals including the water buffalo (Bubalus bubalis) [4] and is recognized as an important cause of abortions and neonatal deaths among populations of susceptible species around the world $[2,5]$. Tissue cysts of

\footnotetext{
* Corresponding author: Cosme Alvarado-Esquivel; Laboratorio de Investigación Biomédica, Facultad de Medicina y Nutrición, Universidad Juárez del Estado de Durango, Avenida Universidad S/N. 34000 Durango, México; Phone/Fax: 0052618 8130527; Email: alvaradocosme@yahoo.com

This is an open-access article distributed under the terms of the Creative Commons Attribution-NonCommercial 4.0 International License (https://creativecommons.org/licenses/by-nc/4.0/), which permits unrestricted use, distribution, and reproduction in any medium for non-commercial purposes, provided the original author and source are credited, a link to the CC License is provided, and changes - if any - are indicated.
} 
$N$. caninum have been found in aborted fetuses of water buffaloes with encephalitis and myocarditis [6]. Neosporosis in water buffaloes has economic importance in several countries including Brazil, India, Italy, and Vietnam [3]. Seroprevalence of $N$. caninum in water buffaloes varies among countries; for instance, $34.6 \%$ in southern Italy by the indirect florescence antibody test (IFAT) [6], 64\% and $53 \%$ in female water buffaloes in Sao Paulo State, Brazil by IFAT and Neospora agglutination test, respectively [7], and $64 \%$ in northeast Argentina by IFAT [8].

Bacteria of the genus Leptospira cause leptospirosis, which is a zoonotic disease of global importance [9, 10]. Infection with Leptospira occurs in more than 160 species of domestic and wild animals [11]. Serological evidence of Leptospira infection has been reported in water buffaloes $[12,13]$, especially in those 3 to 5 years old [14]. Diverse seroprevalence rates of Leptospira infection in water buffaloes obtained by microscopic agglutination test (MAT) among countries have been reported, e.g., $22 \%$ in northeast Argentina [15], 29\% in Egypt [16], 30.5\% in Thailand [17], and 48\% in Philippines [18].

Bovine herpesvirus type 1 is a pathogen that causes infectious bovine rhinotracheitis, abortion, infectious pustular vulvovaginitis, balanoposthitis, and neurological and systemic disease in cattle [19]. Water buffaloes are susceptible to this virus $[20,21]$. Seroprevalence of bovine herpesvirus type 1 in water buffaloes obtained by microserum neutralization test varied from $14.7 \%$ in Brazil [22] to $85 \%$ in India [23].

Water buffalo raising is gaining popularity in Mexico as an alternative livestock production system [24]. In the Mexican state of Veracruz, water buffalo and cattle can share the agroecosystem $[25,26]$. Preliminary findings highlighted the risk for infection with $N$. caninum, Leptospira, and bovine herpesvirus type 1 in water buffaloes in Mexico [24]. Therefore, this study aimed to: (1) determine the seroprevalence of infection with $N$. caninum, Leptospira, and bovine herpesvirus type 1 in water buffaloes (Bubalus bubalis) in Veracruz State, Mexico and (2) determine the risk factors associated with these infections in the water buffaloes studied.

\section{Materials and methods}

\section{Study design and place of the study}

A cross-sectional study was performed in five ranches, also known as bovine production units (BPU), where water buffaloes (Bubalus bubalis) were raised and located in the municipalities of Isla, Juan Rodríguez Clara y Sayula de Alemán in the south of Veracruz State, México, from August 2012 to July 2014. The Isla municipality $\left(18^{\circ}\right.$ $01^{\prime} 45^{\prime \prime} \mathrm{N}$; $95^{\circ} 31^{\prime} 35^{\prime \prime} \mathrm{W}$ ) has an altitude of $60 \mathrm{~m}$ above sea level, a warm-humid climate, an average annual temperature of $24.9{ }^{\circ} \mathrm{C}$, and a mean annual precipitation of $2316 \mathrm{~mm}$. The Juan Rodriguez Clara municipality (17 $59^{\prime}$ $35^{\prime \prime} \mathrm{N}$; $95^{\circ} 24^{\prime} 06^{\prime \prime} \mathrm{W}$ ) has an altitude of 130 meters above sea level, a warm climate, an average annual temperature of $25.0^{\circ} \mathrm{C}$, and a mean annual precipitation of $1266 \mathrm{~mm}$. The Sayula de Alemán municipality ( $17^{\circ} 52^{\prime} 50^{\prime \prime} \mathrm{N}$; $94^{\circ}$ $57^{\prime} 34^{\prime \prime} \mathrm{W}$ ) has an altitude of $80 \mathrm{~m}$ above sea level, a warm climate, an average annual temperature of $27.0^{\circ} \mathrm{C}$, and a mean annual precipitation of $1650 \mathrm{~mm}$.

\section{Buffaloes studied and sampling}

One hundred and forty-four buffaloes (21 males and 123 females) were studied. All water buffaloes were raised under an extensive system. A convenience sampling was used in this study. Blood $(10 \mathrm{ml})$ was drawn from buffaloes by direct jugular venipuncture. Sera samples obtained by blood centrifugation were kept frozen at $-20{ }^{\circ} \mathrm{C}$ until tested. Data about ranches and buffaloes were obtained with the aid of a questionnaire. Information gathered included ranch identification, number of animals, handling of placentas and fetuses, presence of dogs, type of feeding, cohabitation with cows, and water supply. Additionally, data about age, weight, type of reproductive stage (bull calves, studs, heifers, female buffaloes), and reproductive history (abortions, deliveries) of buffaloes were obtained.

\section{Laboratory tests}

Anti-N. caninum IgG antibodies were detected by a commercially available enzyme immunoassay (EIA) "IDEXX Neospora Ab test" (IDEXX ${ }^{\circledR}$ Laboratories, Westbrook, USA). This test has a sensitivity of $100 \%$ and a specificity of $98.9 \%$. Anti-Leptospira interrogans antibodies were detected by MAT. A panel of nine leptospiral serovars was used: Canicola, Hardjo, Icterohaemorrhagiae, Pomona, Pyrogenes, Autumnalis, Ballum, Wolfi, and Muenchen. Anti-bovine herpesvirus type 1 antibodies were detected by a commercially available EIA (HerdChek IBRgB, IDEXX $^{\circledR}$ Laboratories). This test has a sensitivity of $97.4 \%$ and a specificity of $92.4 \%$.

\section{Statistical analysis}

Results were analyzed with the aid of the software STATA version 11.0. Seroprevalence of each infection was calculated. The association of infections with general data of ranches and buffaloes was analyzed by $X^{2}$ and by logistic regression. Odds ratios (ORs) and 95\% confidence intervals (CIs) were also calculated. $P$ values of $<0.05$ were considered as statistically significant.

\section{Ethics statement}

This project was approved by the Bioethics and Animal Welfare Commission of the Veterinary Medicine and Animal Husbandry School (Facultad de Medicina Veterinaria 
y Zootecnia) of the State University of Veracruz (Universidad Veracruzana). Consent for the field research was obtained from the water buffalo ranchers.

\section{Results and discussion}

Of the 144 buffaloes studied, 35 (24.3\%; 95\% CI, 17.732.2) were positive to anti-N. caninum antibodies. Buffaloes seropositive for $N$. caninum were found in all $5 \mathrm{BPU}$ studied. Table 1 shows the seroprevalences of $N$. caninum, Leptospira, and bovine herpesvirus type 1 and how they correlated with the buffalo BPU. The seroprevalence of $N$. caninum found in the present study is higher than those reported in other countries using EIA. For instance, Huong et al. reported a $1.5 \%$ seroprevalence in water buffaloes in southern Vietnam [27], whereas other researchers found no cases of $N$. caninum infection in the herds studied in China [28] or in the Peruvian Amazon [29]. Flores et al. found a seroprevalence of $14.6 \%$ in water buffaloes in Rio Grande do Sul State, Brazil [30]. In the present study, the higher seroprevalences of $N$. caninum infection were observed in buffaloes aged less than 1 year $(40 \% ; 95 \% \mathrm{CI}, 13.7-72.6)$ and in those aged $\geq 7$ years (41\%; 95\% CI, 21.5-63.3). Table 2 shows the seroprevalences of infections and their correlation with age groups of buffaloes. The seroprevalence of $N$. caninum infec- tions in water buffaloes increased with age [8, 31]. The high seroprevalence of $N$. caninum infection in the oldest buffaloes found in our study is consistent with finding of other reports, e.g., in an Italian study, Guarino et al. found a higher $(43.1 \%)$ seroprevalence of $N$. caninum infection in water buffaloes aged $>6$ years than in those $1-2$ years $(24.5 \%)$ [6]. Concerning the reproductive stage of buffaloes, female buffaloes with 1 delivery had the highest seroprevalence of $N$. caninum infection $(33.3 \%$; 95\% CI, 18.6-52.0). The correlation of seroprevalence of infections and reproductive stage of buffaloes is shown in Table 3. Seropositive buffaloes were found in all reproductive stages of buffaloes. The high seroprevalence of $N$. caninum in female buffaloes with 1 delivery might be due to an old age of these animals. The older the animals, the longer the time for a likely expose to $N$. caninum [3]. In our study, none of the characteristics of the ranches examined including ranch, number of animals, handling of placentas and fetuses, presence of dogs, type of feeding, cohabitation of cows, and water supply, or characteristics of the water buffaloes examined including age, weight, reproductive stage, and reproductive history were associated with $N$. caninum infection by logistic regression. Coyotes and dogs were present in the ranches examined; however, their presence was not associated with $N$. caninum infection. Therefore, other infection routes may have contributed to infection in the water buffaloes, e.g., trans-

Table 1. Seroprevalences of infections in the water buffaloes and their correlation with each bovine production unit (BPU)

\begin{tabular}{|c|c|c|c|c|c|c|c|}
\hline \multirow[b]{2}{*}{ BPU } & \multirow{2}{*}{$\begin{array}{c}\begin{array}{c}\text { No. of } \\
\text { buffaloes }\end{array} \\
\text { tested }\end{array}$} & \multicolumn{2}{|c|}{$\begin{array}{c}\text { Positive to } \\
\text { anti-N. caninum }\end{array}$} & \multicolumn{2}{|c|}{$\begin{array}{l}\text { Positive to } \\
\text { anti-Leptospira }\end{array}$} & \multicolumn{2}{|c|}{$\begin{array}{l}\text { Positive to } \\
\text { anti-BHV* }\end{array}$} \\
\hline & & No. & $\%$ & No. & $\%$ & No. & $\%$ \\
\hline 1 & 7 & 1 & 14.3 & 5 & 71.4 & 6 & 85.7 \\
\hline 2 & 56 & 11 & 19.6 & 16 & 28.6 & 26 & 46.6 \\
\hline 3 & 42 & 10 & 23.9 & 20 & 47.6 & 38 & 90.5 \\
\hline 4 & 5 & 2 & 40.0 & 1 & 20.0 & 2 & 40.0 \\
\hline 5 & 34 & 11 & 32.4 & 8 & 23.6 & 11 & 32.4 \\
\hline Total & 144 & 35 & 24.3 & 50 & 34.7 & 83 & 57.6 \\
\hline
\end{tabular}

*Bovine herpesvirus type 1

Table 2. Seroprevalences of infections in the water buffalos and their correlation with age

\begin{tabular}{|c|c|c|c|c|c|c|c|}
\hline \multirow[b]{2}{*}{ Age (years) } & \multirow{2}{*}{$\begin{array}{c}\begin{array}{c}\text { No. of } \\
\text { buffaloes }\end{array} \\
\text { tested }\end{array}$} & \multicolumn{2}{|c|}{$\begin{array}{c}\text { Positive to } \\
\text { anti- } N \text {. caninum }\end{array}$} & \multicolumn{2}{|c|}{$\begin{array}{c}\text { Positive to } \\
\text { anti-Leptospira }\end{array}$} & \multicolumn{2}{|c|}{$\begin{array}{l}\text { Positive to } \\
\text { anti-BHV* }\end{array}$} \\
\hline & & No. & $\%$ & No. & $\%$ & No. & $\%$ \\
\hline$<1$ & 10 & 4 & 40 & 1 & 10 & 6 & 60 \\
\hline $1-2$ & 45 & 8 & 17.8 & 8 & 17.8 & 9 & 20 \\
\hline $3-4$ & 42 & 10 & 23.8 & 17 & 40.5 & 24 & 57.1 \\
\hline $5-6$ & 25 & 4 & 16 & 13 & 52 & 23 & 92 \\
\hline$>7$ & 22 & 9 & 41 & 11 & 50 & 21 & 95.5 \\
\hline
\end{tabular}

*Bovine herpesvirus type 1 
Table 3. Seroprevalences of infections in the water buffalos and their correlation with reproductive stage

\begin{tabular}{|c|c|c|c|c|c|c|c|}
\hline \multirow[b]{2}{*}{ Stage } & \multirow{2}{*}{$\begin{array}{c}\begin{array}{c}\text { No. of } \\
\text { buffaloes }\end{array} \\
\text { tested }\end{array}$} & \multicolumn{2}{|c|}{$\begin{array}{l}\text { Positive to } \\
\text { anti- } N \text {. caninum }\end{array}$} & \multicolumn{2}{|c|}{$\begin{array}{l}\text { Positive to } \\
\text { anti-Leptospira }\end{array}$} & \multicolumn{2}{|c|}{$\begin{array}{l}\text { Positive to } \\
\text { anti-BHV* }\end{array}$} \\
\hline & & No. & $\%$ & No. & $\%$ & No. & $\%$ \\
\hline Bull calves & 13 & 4 & 30.8 & 1 & 7.8 & 7 & 54.0 \\
\hline Studs & 8 & 1 & 12.5 & 3 & 37.5 & 8 & 100.0 \\
\hline Heifers & 48 & 7 & 14.6 & 14 & 29.2 & 12 & 25.0 \\
\hline Female buffalo with 1 delivery & 33 & 11 & 33.3 & 11 & 33.3 & 17 & 51.5 \\
\hline Female buffalo with 2 deliveries & 42 & 12 & 28.6 & 21 & 50.0 & 39 & 93.0 \\
\hline
\end{tabular}

*Bovine herpesvirus type 1

placental infection as reported by other researchers $[3$, 32].

With respect to Leptospira infection, 50 of the 144 water buffaloes examined had antibody titers of $>1: 100$. Thus, the seroprevalence of Leptospira infection in the water buffaloes studied was $34.7 \%$ (95\% CI, 27.1-43.2). Seroprevalence of Leptospira infection varied among the buffalo BPU (Table 1). The frequencies of leptospiral serovars in the 144 water buffaloes examined were as follows: Muenchen in 27 (18.7\%; 95\% CI, 13.1-26.3), Hardjo LT in 15 (10.4\%; 95\% CI, 6.1-16.9), Pyrogenes in $13(9.0 \% ; 95 \% \mathrm{CI}, 5.1-15.2)$, and Icterohaemorrhagiae in $7(4.8 \%$; $95 \% \mathrm{CI}, 2.1-10.1)$. We compared those seroprevalence results with data reported elsewhere using the same MAT. The seroprevalence of Leptospira infection found in water buffaloes in the present study is lower than the $67.2 \%$ reported in water buffaloes in Italy [33]. The leptospiral serovars found in the present study also differ from those reported in the Italian study where researchers found that serovars Sejroe, Hardjo bovis, and Icterohaemorrhagiae were predominant. In contrast, the seroprevalence found in water buffaloes in Mexico is higher than the $17.0 \%$ seroprevalence of Leptospira infection in water buffaloes in India [12]. The leptospiral serovars reported in the Indian study also differ from the ones found in the present study. The leptospiral serovars Hardjo and Andamana were predominant in the Indian study. On the other hand, our seroprevalence is similar to the $33.3 \%$ seroprevalence of Leptospira infection reported in water buffaloes in the sub-Himalayan Kumaon region [14]. In the present study, the seroprevalence of Leptospira infection increased with age in the water buffaloes. This observation agrees with findings reported by other researchers [14, 34]. Table 2 shows a correlation of Leptospira seropositivity and buffalo age groups. With respect to reproduction stage, we observed that female buffaloes with $\geq 2$ deliveries had the highest seroprevalence of Leptospira infection (50\%; 95\% CI, 35.5-64.5) (Table 3). This finding might be due to increased age in these animals. Logistic regression showed that Leptospira infection was associated with cohabitation of water buffaloes with female bovines (OR, 2.2; 95\% CI, $1.04-4.5 ; P=0.03)$. Other characteristics of the ranches examined including location, number of animals, handling of placentas and fetuses, presence of dogs, type of feeding, and water supply, or characteristics of the water buffaloes examined including age, weight, reproductive stage, and reproductive history were not associated with Leptospira infection by logistic regression. The leptospiral serovars Muenchen and Icterohaemorrhagiae have been associated with infection in rats, and the serovar Hardjo with cattle [34]. Our findings highlight the importance of contact with cattle for Leptospira transmission and suggest the likely contributing role of rats for Leptospira transmission in the water buffaloes examined.

Concerning infection with the bovine herpesvirus type 1, we found a seroprevalence of $57.6 \%(95 \%$ CI, 49.1-65.7). This infection was more frequent than $N$. caninum and Leptospira infections in the water buffaloes studied. Infection with bovine herpes virus was found in all the buffalo BPU studied (Table 1). In a study in India, researchers found a $13.5 \%$ seroprevalence of this infection in buffalo bulls [35]. In the present study, stratification by age showed that water buffaloes $\geq 7$ years old had the highest seroprevalence of bovine herpesvirus infection (95.5\%; 95\% CI, 75.1-99.8) (Table 2). This finding is in line with an increase of bovine herpes virus prevalence with age [36]. As to reproductive stage, the highest seroprevalence was found in studs $(100 \% ; 95 \%$ CI, 60-100) and female buffaloes with $\geq 2$ deliveries (93\%; 95\% CI, 79.5-98.1) (Table 3). This is likely due to the increased age of these animals. Logistic regression showed that bovine herpesvirus infection was associated with cohabitation of water buffaloes with female bovines (OR, 12.0; 95\% CI, 4.0-36.2; $P<0.01$ ). Other characteristics of the ranches and water buffaloes examined were not associated with bovine herpesvirus infection by logistic regression. All studs examined were seropositive to bovine herpesvirus, and sexual transmission might have contributed to infection in female buffaloes. However, secretions of the virus in nose but not in vagina have been demonstrated in experimental infections in buffaloes [37]. Therefore, infection acquired by contact with nasal secretion may be more efficient for virus transmission than the sexual route. Cohabitation with cattle has been reported as a transmission route for bovine herpesvirus infection in water buffaloes [36]. This route of transmission also predisposed buffaloes in Veracruz, Mexico to infection with bovine herpesvirus infection. 


\section{Conclusions}

This was the first seroepidemiological study on $N$. caninum, Leptospira, and bovine herpesvirus type 1 infection in water buffaloes in Mexico. Results provided serological evidence of these infections in water buffaloes in the southern Mexican state of Veracruz. Serovars of Leptospira were determined. Cohabitation with cattle was an important factor for the transmission of Leptospira and bovine herpesvirus in water buffaloes.

\section{Funding sources}

This study was financially supported by the National Council for Science and Technology (Consejo Nacional de Ciencia y Tecnología - CONACYT), Mexico, and the State Government of Veracruz (project no. 37066), Mexico.

\section{Competing interests}

The authors declare that they have no competing interests.

\section{Acknowledgements}

The authors thank the buffalo producers for their collaboration to set this work done. They are grateful to the staff of the Parasitology Laboratory of the Veterinary School of the State University of Veracruz and the undergraduate students for their support to accomplish this study. USDA is an equal opportunity provider and employer.

\section{References}

1. Radostits OM, Gay CC, Blood DC, Hinchcliff KW (2002): Medicina veterinaria, tratado de las enfermedades del ganado bovino, ovino, porcino, caprino y equinos, 9th edition, Vol. 2, Editorial Mc Graw-Hill Interamericana

2. Dubey JP, Lindsay DS: A review of Neospora caninum and neosporosis. Vet Parasitol 67, 1-59 (1996)

3. Dubey JP: Review of Neospora caninum and neosporosis in animals. Korean J Parasitol 41, 1-16 (2003)

4. Dubey JP, Romand S, Hilali M, Kwok OC, Thulliez P: Seroprevalence of antibodies to Neospora caninum and Toxoplasma gondii in water buffaloes (Bubalus bubalis) from Egypt. Int J Parasitol 28, 527-529 (1998)

5. Anderson M, Andrianarivo A, Conrad P: Neosporosis in cattle. Anim Reprod Sci 61, 417-431 (2000)

6. Guarino A, Fusco G, Savini G, Di Francesco G, Cringoli G: Neosporosis in water buffalo (Bubalus bubalis) in southern Italy. Vet Parasitol 91, 15-21 (2000)

7. Fujii TU, Kasai N, Nishi SM, Dubey JP, Gennari SM: Seroprevalence of Neospora caninum in female water buffaloes (Bubalus bubalis) from the southeastern region of Brazil. Vet Parasitol 99, 331-334 (2001)
8. Campero CM, Pérez A, Moore DP, Crudeli G, Benitez D, Draghi MG, Cano D, Konrad JL, Odeón AC: Occurrence of antibodies against Neospora caninum in water buffaloes (Bubalus bubalis) on four ranches in Corrientes province, Argentina. Vet Parasitol 150, 155-158 (2007)

9. Levett NP: Leptospirosis: a forgotten zoonosis? Clin Appl Immunol Rev 4, 435-448 (2004)

10. Pinto PS, Libonati H, Lilenbaum W: A systematic review of leptospirosis on dogs, pigs, and horses in Latin America. Trop Anim Health Prod 49, 231-238 (2017)

11. Torres-Castro M, Hernández-Betancourt S, Agudelo-Flórez P, Arroyave-Sierra E, Zavala-Castro J, Puerto FI: Current review of the epidemiology of leptospirosis. Rev Med Inst Mex Seguro Soc 54, 620-625 (2016)

12. Ramani PR, Punya KB: Seroprevalence of leptospirosis in domestic animals. Indian Vet J 82, 670-671 (2005)

13. Priyantha MA, Gunawardana GA, Puvanenderan S, Wijemuni MI, Alwis PS: Serological detection of Leptospira serovars form aborted water buffaloes in Sri Lank. In 9th World Buffalo Congress. Buenos Aires, Argentina 480 $483(2010)$

14. Dwivedi HP, Kumar M, Srivastava SK: Risk factors analysis for prevalence of different Leptospira sp. in ruminants of sub-Himalaya Kumaon region. Indian Vet Med 26, 100 103 (2006)

15. Konrad JL, Moore DP, Crudeli G, Caspe SG, Cano DB, Leunda MR, Lischinsky L, Regidor-Cerrillo J, Odeón AC, Ortega-Mora LM, Echaide I, Campero CM: Experimental inoculation of Neospora caninum in pregnant water buffalo. Vet Parasitol 187, 72-78 (2012)

16. Horton KC, Wasfy M, Samaha H, Abdel-Rahman B, Safwat S, Abdel Fadeel M, Mohareb E, Dueger E: Serosurvey for zoonotic viral and bacterial pathogens among slaughtered livestock in Egypt. Vector Borne Zoonotic Dis 14, 633-639, doi: 10.1089/vbz.2013.1525 (2014)

17. Suwancharoen D, Chaisakdanugull Y, Thanapongtharm W, Yoshida S: Serological survey of leptospirosis in livestock in Thailand. Epidemiol Infect 141, 2269-2277 (2013)

18. Villanueva MA, Mingala CN, Gloriani NG, Yanagihara Y, Isoda N, Nakajima C, Suzuki Y, Koizumi N: Serological investigation of Leptospira infection and its circulation in one intensive-type water buffalo farm in the Philippines. Jpn J Vet Res 64, 15-24 (2016)

19. Raaperi K, Orro T, Viltrop A: Epidemiology and control of bovine herpesvirus 1 infection in Europe. Vet J 201, 249$256(2014)$

20. Muylkens B, Thiry J, Kirten P, Schynts F, Thiry E: Bovine herpesvirus 1 infection and infectious bovine rhinotracheitis. Vet Res 38, 181-209 (2007)

21. Scicluna MT, Caprioli A, Saralli G, Manna G, Barone A Cersini A, Cardeti G, Condoleo RU, Autorino GL: Should the domestic buffalo (Bubalus bubalis) be considered in the epidemiology of Bovine Herpesvirus 1 infection? Vet Microbiol 143, 81-88 (2010)

22. Lage AP, Castro RS, Melo MI, Aguiar PH, Barreto Filho JB, Leite RC: Prevalence of antibodies to bluetongue, bovine herpesvirus 1 and bovine viral diarrhea/mucosal disease viruses in water buffaloes in Minas Gerais State, Brazil. Rev Elev Med Vet Pays Trop 49, 195-197 (1996)

23. Nandi S, Kumar M, Manohar M, Chauhan RS: Bovine herpes virus infections in cattle. Anim Health Res Rev 10, 85-98 (2010) 
24. Romero Salas D, Pérez de León AA (2014): Bubalinocultura en Mexico: retos de industria pecuaria naciente. In: Logros y Desafíos de la Ganadería Doble Propósito, 6th ed, eds. González Stagnaro C, Madrid Bury N, Soto Bellozo E, Fundación GIRARZ: Maracaibo, VN, 707-715

25. Alvarado-Esquivel C, Romero-Salas D, García-Vázquez Z, Cruz-Romero A, Peniche-Cardeña A, Ibarra-Priego N, Aguilar-Domínguez M, Pérez-de-León AA, Dubey JP: Seroprevalence of Toxoplasma gondii infection in water buffaloes (Bubalus bubalis) in Veracruz State, Mexico and its association with climatic factors. BMC Vet Res 10, 232 (2014)

26. Romero-Salas D, Mira A, Mosqueda J, García-Vázquez Z, Hidalgo-Ruiz M, Vela NA, Pérez de León AA, FlorinChristensen M, Schnittger L: Molecular and serological detection of Babesia bovis- and Babesia bigemina-infection in bovines and water buffaloes raised jointly in an endemic field. Vet Parasitol 217, 101-107 (2016)

27. Huong LT, Ljungstrom BL, Uggla A, Bjorkman C: Prevalence of antibodies to Neospora caninum and Toxoplasma gondii in cattle and water buffaloes in southern Vietnam. Vet. Parasitol 75, 53-57 (1998)

28. Yu J, Xia Z, Liu Q, Liu J, Ding J, Zhang W: Seroepidemiology of Neospora caninum and Toxoplasma gondii in cattle and water buffaloes (Bubalus bubalis) in the People's Republic of China. Vet Parasitol 143, 79-85 (2007)

29. Jara VJ, Chávez VA, Casas AE, Sánchez PN, MorenoLópez J, Merza M: Determinación de anticuerpos contra Neospora caninum en búfalos de agua (Bubalus bubalis) en la amazonia peruana. Rev Inv Vet Perú 22, 61-65 (2011)

30. Flores F, Arenhart S, Vicosa F: Anticorpos anti-Neospora caninum em bovines, ovinos e bubalinos no Estado do Rio Grande do Sul. Ciencia Rural 36, 1948-1951 (2006)
31. Moore DP, Odeón AC, Venturini MC, Campero CM: Neosporosis bovina: conceptos generales, inmunidad y perspectivas para la vacunación. Rev Argent Microbiol 37, 217-228 (2005)

32. Chryssafidis LA, Soares MR, Rodrigues AA, Carvalho TN, Gennari SM: Evidence of congenital transmission of Neospora caninum in naturally infected water buffalo (Bubalus bubalis) fetus from Brazil. Parasitol Res 108, 741-743 (2011)

33. Ciceroni L, D'Aniello P, Russo N, Picarella D, Nese D, Lauria F, Pinto A, Cacciapuoti B: Prevalence of Leptospira infections in buffalo herds in Italy. Vet Rec 137, 192-193 (1995)

34. Céspedes ZM: Leptospirosis: enfermedad zoonótica reemergente. Rev Peru Med Exp Salud Pública 22, 290-307 (2005)

35. Nandi S, Kumar M, Yadav V, Chander V: Serological evidences of bovine herpesvirus-1 infection in bovines of organized farms in India. Transbound Emerg Dis 58, 105109 (2011)

36. Ferreira RN, Ribeiro HF, Vale WG, Rolim-Filho ST, Barbosa EM: Prevalence of infectious bovine rhinotracheitis (IBR) in buffalo bulls in Amapá State and Marajo Island, Amazon Basin, Brazil, in 9th World Buffalo Congress. Buenos Aires, Argentina, 475-477 (2010)

37. De Carlo E, Re GN, Letteriello R, Del Vecchio V, Giordanelli MP, Magnino S, Fabbi M, Bazzcocchi C, Bandi C, Galiero G: Molecular characterization of a field strain of bubaline herpesvirus isolated from buffaloes (Bubalus bubalis) after pharmacological reactivation. Vet Rec 154, 171-174 (2004) 